\title{
Breast Cancer: Uses and Opportunities for Molecular Imaging
}

Editors

ELIZABETH S. MCDONALD

GARY A. ULANER

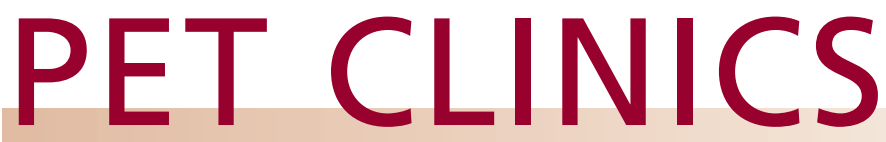

www.pet.theclinics.com

Consulting Editor

ABASS ALAVI

July 2018 • Volume 13 • Number 3 